\title{
The PML-RARA fusion is not detectable in historical blood samples of acute promyelocytic leukaemia patients
}

\author{
William G. Dunn ${ }^{1,2} \cdot$ Muxin S. Gu ${ }^{1,3} \cdot$ Margarete A. Fabre ${ }^{1,2,3} \cdot$ Jonathan Cooper ${ }^{1,3}$. Josep F. Nomdedeu ${ }^{1,3,4}$. \\ Laura Koumas $^{5} \cdot$ Katerina Nicolaou $^{5} \cdot$ Jiangxiang $\mathrm{Chi}^{5} \cdot$ Paul Costeas $^{5,6} \cdot$ George S. Vassiliou ${ }^{1,2,3,5,6} \mathbb{D}$
}

Received: 10 February 2021 / Accepted: 18 February 2021 / Published online: 1 March 2021

(C) The Author(s) 2021

\begin{abstract}
Dear Editor,
Acute promyelocytic leukaemia (APL) is characterized by the presence of the $\mathrm{t}(15 ; 17)$ chromosomal translocation that generates the PML-RARA fusion gene [1].PML-RARA, formed by the fusion of the promyelocytic leukaemia $(P M L)$ and retinoic acid receptor $\alpha(R A R A)$ genes, is a constitutively active nuclear receptor that exerts transcriptional repression of $R A R \alpha$ target genes leading to enhanced self-renewal capacity and myeloid differentiation block [2]. In approximately half of all cases, APL cells harbor additional mutations in genes such as FLT3, WT1, NRAS or KRAS [3, 4]. Mice expressing $P M L-R A R A$ under the control of various promoters develop APL-like disease with variable penetrance and only after a significant period of latency (6-16 months) $[5,6]$. These observations suggest a long latency between PML-RARA acquisition and APL onset, as reported for somatic mutations associated with acute myeloid leukaemia with a normal karyotype (AML-NK) [7]. Here, to investigate whether PML-RARA is detectable in the blood before APL onset, we study four APL
\end{abstract}

Paul Costeas

paul.costeas@karaiskakio.org.cy

George S. Vassiliou

gsv20@sanger.ac.uk

1 Wellcome-MRC Cambridge Stem Cell Institute, Jeffrey Cheah Biomedical Centre, Puddicombe Way, Cambridge CB2 0AW, UK

2 Department of Haematology, Cambridge University Hospitals NHS Trust, Cambridge, UK

3 Wellcome Sanger Institute, Wellcome Genome Campus, Hinxton, Cambridge CB10 1SA, UK

4 Department of Haematology, Hospital de la Santa Creu I Sant Pau, Barcelona, Spain

5 Center for the Study of Haematological Malignancies, Karaiskakio Foundation, Nicosia, Cyprus

6 Cyprus Cancer Research Institute, Nicosia, Cyprus cases with blood DNA available, from the same individual, 212 years before diagnosis.

Four individuals with paired APL and pre-leukaemic blood DNA samples were identified (Fig. 1a). APL DNA samples were shallow whole-genome sequenced on Illumina HiSeq using a 150 bp paired-end protocol preceded by DNA sonication to generate fragments of 450 nucleotides (nt) average length. FASTQ files were aligned to DNA sequences of the $P M L$ and $R A R A$ genes. Aligned reads were analyzed using RNAmut v1.0 [8] and this directly identified the precise location of $3 / 4$ patientspecific breakpoints (by reads crossing the breakpoint), whilst the location of the fourth breakpoint was narrowed to a $20 \mathrm{nt}$ window (Fig. 1b). Patient-specific primer pairs were then designed to amplify across each breakpoint using the polymerase chain reaction (PCR) (Fig. 1c). To determine the sensitivity for detecting each breakpoint by PCR, leukaemic DNA samples were suspended at $20 \mathrm{ng} / \mu \mathrm{L}$ and iteratively diluted tenfold to a dilution of 1:10,000 into equimolar $(20 \mathrm{ng} / \mu \mathrm{L})$ pooled normal blood DNA from 10 healthy subjects. All 4 primer pairs specifically amplified their cognate patient-specific breakpoints (Fig. 1d). Serial dilutions demonstrated sensitivity down to a 1:1000 dilution of cognate APL DNA (equivalent to $200 \mathrm{pg} / \mu \mathrm{L}$ of DNA). Despite this high sensitivity, none of the PML-RARA fusions was identified in their relevant pre-leukaemic samples (Fig. 1d, representative of triplicate PCRs).

In summary, our study of paired DNA samples suggests that the pre-clinical clonal history of APL may not be as long as that of AML-NK, where mutation-bearing clonal hematopoiesis $(\mathrm{CH})$ clones can be detected years in advance of their progression to frank leukaemia ${ }^{11}$. However, with the exception of JAK2 V617F, CH is almost entirely driven by mutations in epigenetic (DNMT3A, TET2, ASXL1, IDH1, IDH2), splicing (SF3B1, SRSF2, U2AF1) or apoptosis-related (TP53, PPM1D) genes $[9,10]$. By contrast, bona-fide leukaemogenic mutations in genes such as NPM1,CEBPA and MLL have not been identified prior to the diagnosis of AML-NK, reflecting what we have observed for PML-RARA. Collectively these 
a

\begin{tabular}{c|cc}
\hline $\begin{array}{c}\text { Patient } \\
\text { ID }\end{array}$ & $\begin{array}{c}\text { Age at APL } \\
\text { diagnosis } \\
\text { (yrs) }\end{array}$ & $\begin{array}{c}\text { Age at normal } \\
\text { blood sample } \\
\text { donation }(y r s)^{*}\end{array}$ \\
\hline A & 38 & 26 \\
B & 39 & 37 \\
C & 50 & 39 \\
D & 33 & 22
\end{tabular}

b

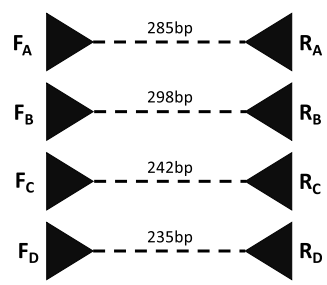

PML

RARA b

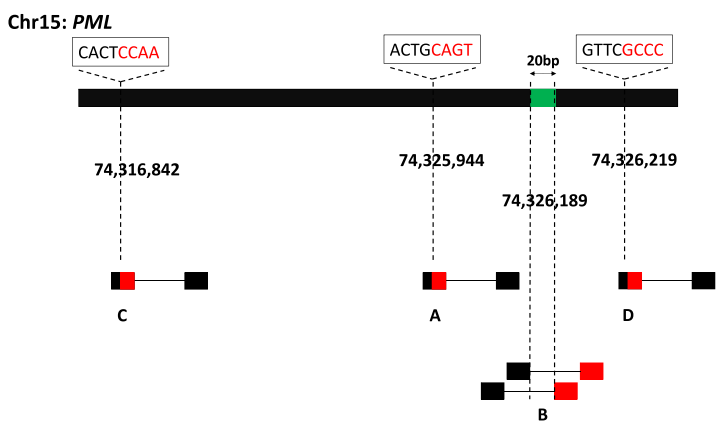

d
1:100

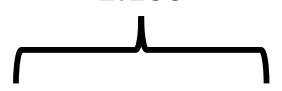

A B C D

Primers A

Primers B

Primers C

Primers D

A

-

0

$-$

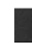
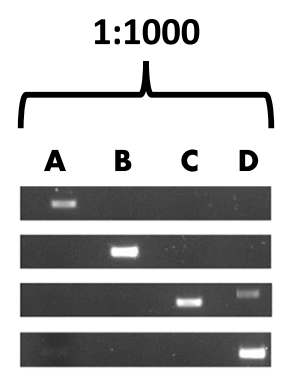

Pre-leukaemia

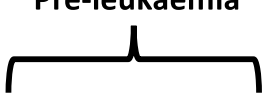

A $\quad$ B $\quad$ C $\quad$ D

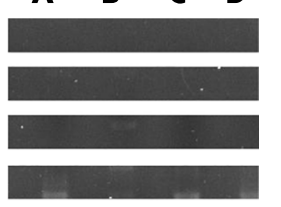

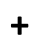

$-$
Fig. 1 PML-RARA is not detectable in blood DNA 2-10 years prior to the diagnosis of APL. a Demographics of patients studied. *Samples were collected for the purposes of registering as blood stem cell donors at the Karaiskakio foundation. $\mathbf{b}$ Identification of chimeric reads crossing the PML-RARA breakpoints in 4 cases of APL (patients A-D). The genomic loci of each breakpoint are highlighted with respect to their position on the PML gene (black) of chromosome 15. Reads mapping to RARA gene (chromosome 17) are highlighted in red. For individual $\mathrm{B}$,

observations suggest that acquisition of such mutations leads to the development of AML after a relatively short time. Alternatively, mutation-bearing cells may not reach the circulation as a consequence of the effects of these mutations in blocking myeloid differentiation [6]. In either case, our findings suggest that, unlike AML-NK [7], APL does not commonly have a long pre-clinical phase that can be detected in the DNA of circulating blood cells.

Code availability The RNAmut package used here to identify breakpoints is available from https://github.com/muxingu/rnamut.

Author contribution G.S.V., P.C. and J.N. conceived and designed the study. G.S.V. supervised the study. W.G.D and G.S.V. design PCR assays. W.G.D. and J.C. performed experiments. M.G. and M.A.F. performed bioinformatic analyses. K.N. and J.X. identified patient samples. W.G.D. and G.S.V wrote the manuscript with input from all co-authors.

Funding This work was funded by the Wellcome Trust (WT098051). G.S.V. is funded by a Cancer Research UK Senior Cancer Fellowship (C22324/A23015) and work in his lab is also funded by the European Research Council, Kay Kendall Leukaemia Fund, Blood Cancer UK, Leukemia Lymphoma Society and Rise Tide Foundation for Clinical Cancer Research. M.A.F. is funded by a Wellcome Clinical Fellowship. the precise breakpoint was not located, but narrowed to a $20 \mathrm{bp}$ window (green). c Patient-specific forward (F) and reverse (R) primers were designed to amplify each $P M L-R A R A$ breakpoint. $\mathbf{d}$ Gel electrophoresis of diluted leukaemia (left and central columns) and neat pre-leukaemia (right column) DNAs following PCR with patient-specific primer pairs. PML primers were used as positive controls $(+)$ and neat normal DNA with patient-specific primers as negative controls (-)

\section{Declarations}

Ethics approval The study was approved by the Cyprus National Bioethics Committee (EEBK/EП/2014/11) and performed in accordance with the Declaration of Helsinki of 1975, as revised in 2008.

Consent to participate Informed consent was obtained from all participants

Consent for publication The authors affirm that all patients who provided peripheral blood samples for the study gave consent for the publication of their anonymized data.

Conflict of interest G.S.V. is a consultant for STRM.BIO and a minor stockholder in KYMAB.

Open Access This article is licensed under a Creative Commons Attribution 4.0 International License, which permits use, sharing, adaptation, distribution and reproduction in any medium or format, as long as you give appropriate credit to the original author(s) and the source, provide a link to the Creative Commons licence, and indicate if changes were made. The images or other third party material in this article are included in the article's Creative Commons licence, unless indicated otherwise in a credit line to the material. If material is not included in the article's Creative Commons licence and your intended use is not permitted by 
statutory regulation or exceeds the permitted use, you will need to obtain permission directly from the copyright holder. To view a copy of this licence, visit http://creativecommons.org/licenses/by/4.0/.

\section{References}

1. de Thé H, Lavau C, Marchio A, Chomienne C, Degos L, Dejean A (Aug 1991) The PML-RAR alpha fusion mRNA generated by the $\mathrm{t}(15 ; 17)$ translocation in acute promyelocytic leukemia encodes a functionally altered RAR. Cell. 66(4):675-684. https://doi.org/10. 1016/0092-8674(91)90113-d

2. Wojiski S, Guibal FC, Kindler T, Lee BH, Jesneck JL, Fabian A, Tenen DG, Gilliland DG (Aug 2009) PML-RARalpha initiates leukemia by conferring properties of self-renewal to committed promyelocytic progenitors. Leukemia. 23(8):1462-1471. https:// doi.org/10.1038/leu.2009.63

3. Papaemmanuil E, Gerstung M, Bullinger L, Gaidzik VI, Paschka P, Roberts ND, Potter NE, Heuser M, Thol F, Bolli N, Gundem G, van Loo P, Martincorena I, Ganly P, Mudie L, McLaren S, O'Meara S, Raine K, Jones DR, Teague JW, Butler AP, Greaves MF, Ganser A, Döhner K, Schlenk RF, Döhner H, Campbell PJ (Jun 2016) Genomic classification and prognosis in acute myeloid leukemia. N Engl J Med 374(23):2209-2221. https://doi.org/10.1056/ NEJMoa1516192

4. Madan V, Shyamsunder P, Han L et al (2016) Comprehensive mutational analysis of primary and relapse acute promyelocytic leukemia. Leukemia 30(12):2430. https://doi.org/10.1038/leu. 2016.237

5. Westervelt P, Lane AA, Pollock JL, Oldfather K, Holt MS, Zimonjic DB, Popescu NC, DiPersio JF, Ley TJ (Sep 2003) High-penetrance mouse model of acute promyelocytic leukemia with very low levels of PML-RARalpha expression. Blood. 102(5):1857-1865. https://doi.org/10.1182/blood-2002-12-3779

6. Grisolano JL, Wesselschmidt RL, Pelicci PG, Ley TJ (Jan 1997) Altered myeloid development and acute leukemia in transgenic mice expressing PML-RAR alpha under control of cathepsin G regulatory sequences. Blood. 89(2):376-387

7. Abelson S, Collord G, Ng SWK et al (2018) Prediction of acute myeloid leukaemia risk in healthy individuals. Nature 559(7714): 400-404. https://doi.org/10.1038/s41586-018-0317-6

8. Gu M, Zwiebel M, Ong SH, Boughton N, Nomdedeu J, Basheer F, Nannya Y, Quiros PM, Ogawa S, Cazzola M, Rad R, Butler AP, Vijayabaskar MS, Vassiliou GS (Oct 2019) RNAmut: robust identification of somatic mutations in acute myeloid leukemia using RNA-seq. Haematologica. 105:e290-e293. https://doi.org/10. 3324/haematol.2019.230821

9. Xie M, Lu C, Wang J, McLellan MD, Johnson KJ, Wendl MC, McMichael JF, Schmidt HK, Yellapantula V, Miller CA, Ozenberger BA, Welch JS, Link DC, Walter MJ, Mardis ER, Dipersio JF, Chen F, Wilson RK, Ley TJ, Ding L (Dec 2014) Age-related mutations associated with clonal hematopoietic expansion and malignancies. Nat Med 20(12):1472-1478. https://doi.org/ 10.1038/nm.3733

10. Jaiswal S, Fontanillas P, Flannick J, Manning A, Grauman PV, Mar BG, Lindsley RC, Mermel CH, Burtt N, Chavez A, Higgins JM, Moltchanov V, Kuo FC, Kluk MJ, Henderson B, Kinnunen L, Koistinen HA, Ladenvall C, Getz G, Correa A, Banahan BF, Gabriel S, Kathiresan S, Stringham HM, McCarthy MI, Boehnke M, Tuomilehto J, Haiman C, Groop L, Atzmon G, Wilson JG, Neuberg D, Altshuler D, Ebert BL (Dec 2014) Age-related clonal hematopoiesis associated with adverse outcomes. N Engl J Med 371(26):2488-2498. https://doi.org/10.1056/NEJMoa1408617

Publisher's note Springer Nature remains neutral with regard to jurisdictional claims in published maps and institutional affiliations. 